\title{
Assessment of factors Influencing Communication among bottom line and top management in Construction Industry
}

\author{
Pradeep. $\mathbf{T}^{\mathbf{1}}$, Umadevi. $\mathbf{P}^{\mathbf{2}}$ \\ $1 *$ Associate Professor, Department of Civil Engineering, Kongu Engineering College, \\ Erode, India \\ 2PG student, Department of Civil Engineering, Kongu Engineering College, Erode, \\ India \\ Corresponding Author E-mail: pradeep5678t@gmail.com
}

\begin{abstract}
In day-to-day life the construction industry has become active with more desgins and construction project. Their emerging field existence involves management and execution by highly qualified and task coordinated project team from various organization. Throughout the project, required information must be identified and discussed amount of information flows among the entire workers in the construction industry. Few factors has been identified through the research. The identified factors are inaccuracy, misunderstanding, barriers, project complexity, timeliness, project communication media, arrangement of organization of structure, trust among workers, project culture, clarity in information. The questionnaire design was prepared after the identification offactors and circulated among more companies. The most affected critical factors are misunderstanding, Barriers, Project complexity, Communication media, Organization structure. The supervisor has the ability to solve the problem between the labors ranks 1 and the factor trust among the workers is more. The factors were analyzed by using SPSS software and relative important index was calculated to rank the factors.
\end{abstract}

Keywords: Poor Communication, Top management, Bottom line, Relative important index, Communication media, Construction.

\section{Introduction}

The construction industry differs for other industry as it has unique structures and characteristics. It involves many parties therefore effective communication is required to overcome the strategies (Gamil Y et al., 2017). Communication is a stream that transports information from one person to other person. Communication within the construction presents a special challenge (Aulich T 2013). Many of the problems occurs in the construction industry are result of temporary and inter disciplinary nature of project team members. These projects require highly trained and task organized team for management and execution (Olanrewaju A et al., 2017). Mostly the multidisciplinary organization exchange more number of information and data. The information and data should be identified and distributed among the team members (Thomas SR et al., 1999). The project 
team need clear and timely information about the project works so that they can make proper decisions to make success in project. The project failure occurs due to poor communication among the team members (Crampton SM at al., 1998).

The poor communication is described as ineffective communication or lack of communication which should avoided in the construction site (Hoezen M et al., 2006). To have smooth information flow the communication system should link the projects team members. If there is a clear information between team members, technical information can be communicated easily and team work will be improved.

\section{Materials and Methodology}

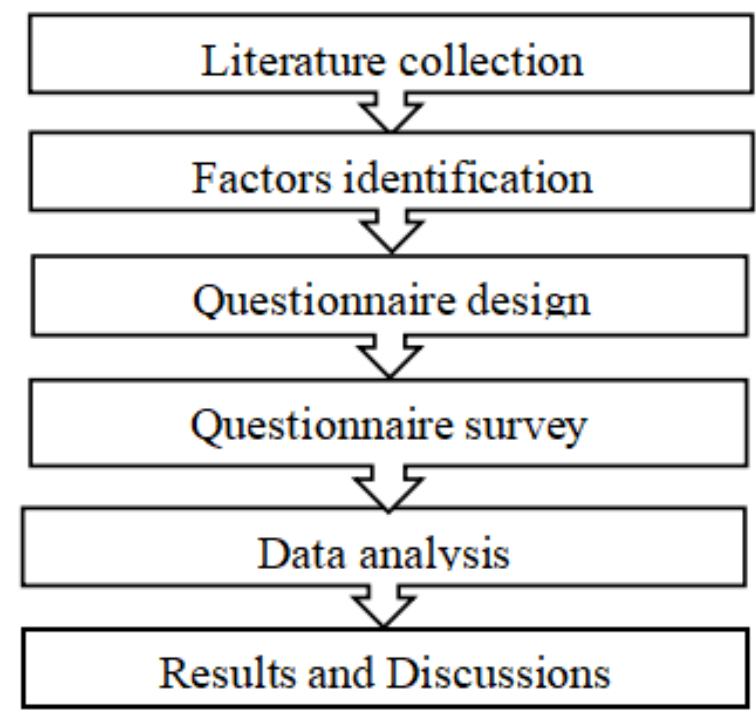

Figure 1 Methodology

Through the literature survey the factors has been identified and the questionnaire were designed and circulated among the workers in the construction site. Responses has been collected and analyzed by using SPSS. The methodology has been represented as figure 1.

\subsection{Types of Communication in Construction Industry}

Understanding the concept and meaning of communication in construction industry is very difficult due to different people comes from different places (Chmielecki M, 2015). The communication can be classified in four types. They are intrapersonal communication, interpersonal communication, small-group communication, multi-group communication. The intrapersonal communication enables an individual to process the information. The inter-personal enables the individual to establish and maintain the relationship. The smallgroup used to coordinate the activities among the work group. The multi-group used to coordinate activities among different groups. Communication in construction industry is classified as internal and external communication. Internal communication is done within the project and external communication done to the clients, customers etc (Mitkus $\mathrm{S}$ et al., 2014). 


\section{Project Team Members in Construction Industry}

The completion of project depends upon the project team members. Different project teams works at different types of project. The communication process is not only a information flow but also a mutual understanding between the workers (Anumba $\mathrm{C}$ et al., 1997). The project team communication includes Information transmission, Work coordination, and Relationship management.

\subsection{Information Transmission}

The communication process in the project team is the information is delivered and exchanged between the team members.this information will be quantitative and consists of designs, schedule, plan.

\subsection{Work Coordination}

The communication process in the project team is the information is delivered and exchanged between the team members.this information will be quantitative and consists of designs, schedule, plan.

\subsection{Relationship Management}

In the project team the workers comes from different organization and have different perceptions on work.

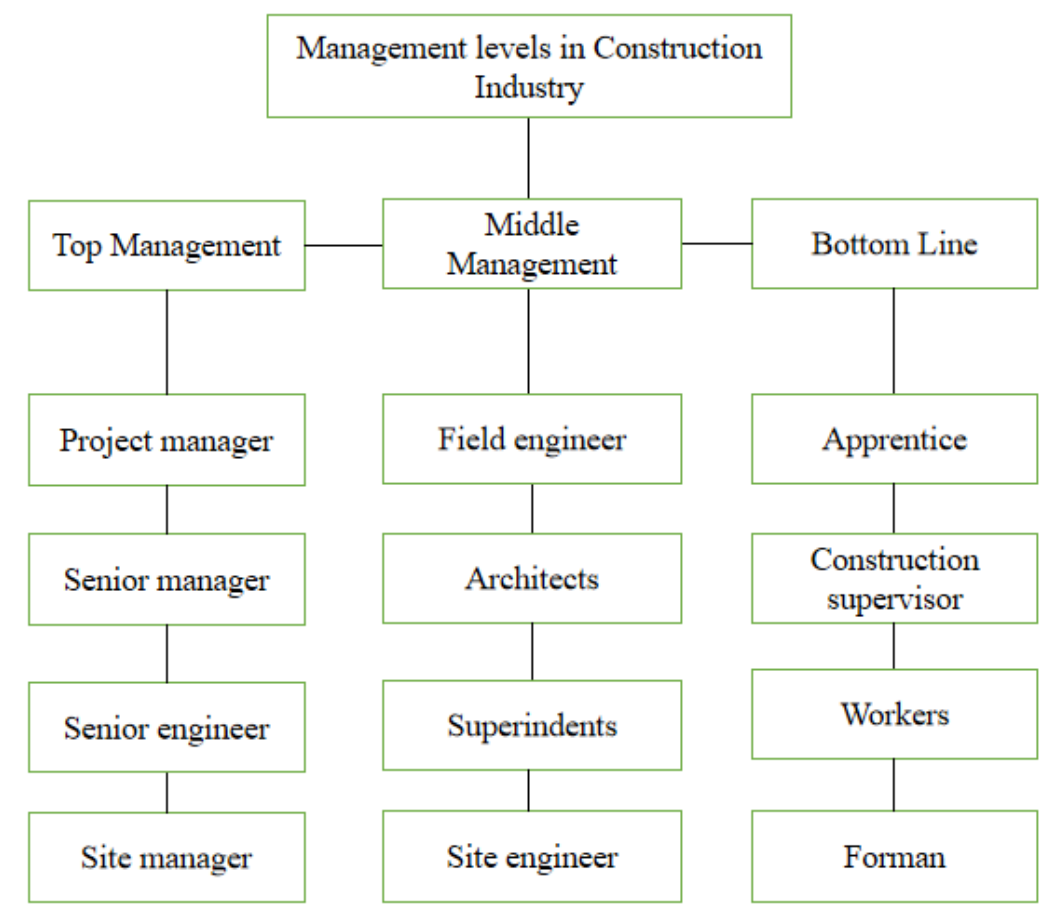

Figure 2 Management levels in construction industry

To influence others and maintain good relationships, one person can use range of communication technique. This form of communication is typically achieved by a representative of company and personal interaction. The management levels has been represented as figure 2 . 


\section{Factor Identification}

The factors influencing the communication are identified. The main factors of communication in construction industry are inaccuracy, misunderstanding, untimeliness, barriers, project complexity, communication media, organization structure, project culture, trust, working environment.

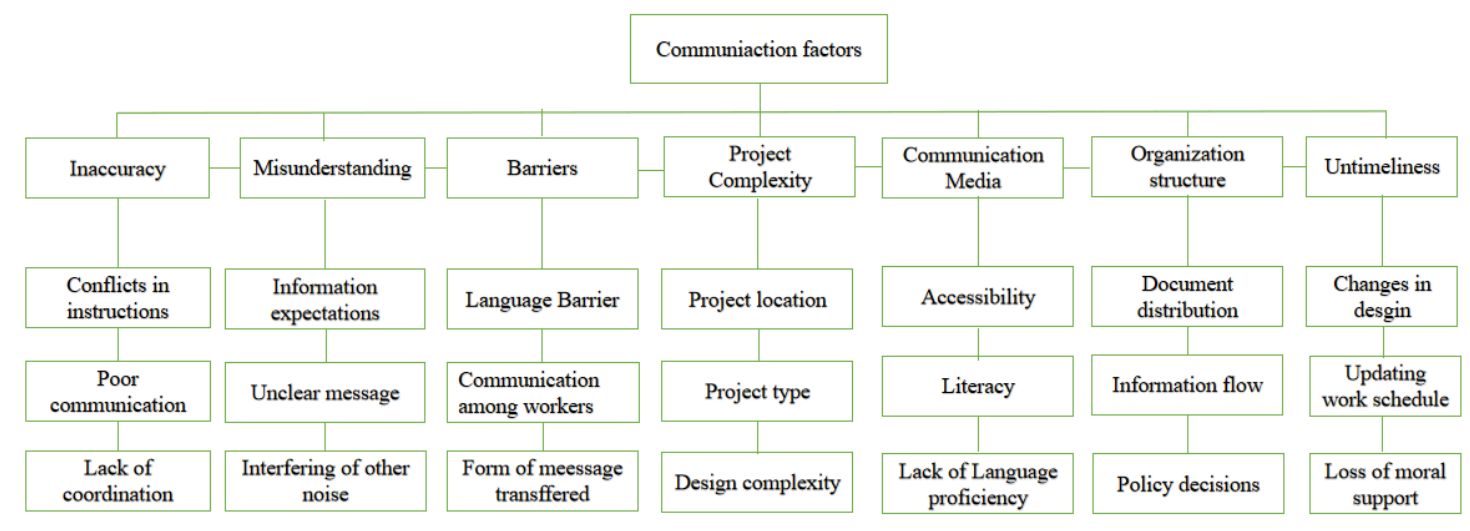

Figure.3. critical communication factors

\subsection{Inaccuracy}

The indicators of inaccuracy was poor communication and lack of team work. Several researchers have identified conflicting, inconsistent instructions and direction as important communication problem (Shindina T, 2016). The best way to organize the team work is to communicate among project workers. As a result the inaccuracy the communication and lack of communication indicates inaccuracy of communication.

\subsection{Misunderstanding}

Misunderstanding is described as a distortion of information expectations and requirements between workers. In return for communication to be accurate, it must provide information that fulfills the standards and needs to workers (Bowen PA, 1996). It is necessary for the sender to understand fully the contacts requirements. Understanding the expectation in information of others is very difficult.

\subsection{Barriers}

Barriers are described as the presence of interpersonal, availability, organizational and other barriers that interrupt and restrict communication among the workers. Barriers are the common communication issue among the project members. In effective communication the information should be provided to right workers. Design and drawings should be maintained correctly so that they can be accessed easily.

\subsection{Project Complexity}

Project complexity is one of the factor that affects the communication. The project complexity occurs due to location of the project, size of the project, type of the project and complexity of design. 


\subsection{Media for Communication}

The media is a tool to transfer information to one person to other. The information can be passed through postal letter, electronic mails, telephone, fax, meetings and face to face conversation. The communication media can be classified into three methods. Oral, nonverbal and written (Cheng EW et al., 2001). Oral speech can be done like speeches and group discussions. Non verbal communication like face expression, body language. Written media is like letters, fax, electronic mails, notices etc. It is important to use appropriate media to transfer information and promote the communication process in order to ensure that communication has the desired results. Different types of media have different characteristics. The choice of the media depends on the nature of the working site. The richness of communication media varies, as do their capacities for processing accuracy of data.

\subsection{Arrangement of organization structure}

Organization communication mainly depends on the structure of the organization. The communication can be evaluated by the positional responsibilities (Aiyewalehinmi E, 2013). The communication is related among positions within an organization. The required information for the workers are related to organization responsibilities.

\subsection{Untimeliness}

The untimeliness includes the updating the changes made in the designs and drawings. The main responsibility for the management is to receive the information timely. So that the every member in the project can access the information clearly. The critical factors have been identified and represented as figure 3 .

\subsection{Analysis}

The Questionnaire was prepared and distributed to the construction companies. The responses were collected from different levels of management. It was done by the means of google forms. Percentage of responses for each questionnaire were collected. The analysis shows how the factor which leads to communicate in project. The frequency analysis was used to analyze the factors and relative important index was calculated to rank the factors. The results are mentioned below in table1. The analysis was done by using SPSS.

Table 1 Results of Frequency analysis

\begin{tabular}{|l|l|l|l|l|l|l|l|l|}
\hline $\begin{array}{l}\text { Sl.n } \\
\text { o }\end{array}$ & Statement & $\begin{array}{l}\text { Mea } \\
\mathbf{n}\end{array}$ & $\begin{array}{l}\text { Media } \\
\mathbf{n}\end{array}$ & $\begin{array}{l}\text { Mod } \\
\mathbf{e}\end{array}$ & $\begin{array}{l}\text { Standa } \\
\text { rd } \\
\text { deviatio } \\
\mathbf{n}\end{array}$ & $\begin{array}{l}\text { Varian } \\
\text { ce }\end{array}$ & RII & Rank \\
\hline 1 & $\begin{array}{l}\text { Familiar with other } \\
\text { workers roles and } \\
\text { responsibilities }\end{array}$ & 3.63 & 4.00 & 4.00 & 0.942 & 0.888 & $\begin{array}{l}0.47 \\
3\end{array}$ & 18 \\
\hline 2 & The information & 3.78 & 4.00 & 4.00 & 0.905 & 0.819 & 0.43 & 19 \\
\hline
\end{tabular}




\begin{tabular}{|c|c|c|c|c|c|c|c|c|}
\hline & $\begin{array}{l}\text { given by the } \\
\text { engineers are } \\
\text { distributed to every } \\
\text { workers }\end{array}$ & & & & & & 6 & \\
\hline 3 & $\begin{array}{l}\text { Disputes may occur } \\
\text { between the } \\
\text { workers while } \\
\text { working at worksite }\end{array}$ & 3.57 & 4.00 & 4.00 & 0.721 & 0.521 & $\begin{array}{l}0.50 \\
5\end{array}$ & 16 \\
\hline 4 & $\begin{array}{l}\text { The theoretical } \\
\text { concepts are } \\
\text { applied in the actual } \\
\text { field by the } \\
\text { supervisors }\end{array}$ & 2.97 & 3.00 & 4.00 & 1.24 & 1.54 & $\begin{array}{l}0.60 \\
5\end{array}$ & 13 \\
\hline 5 & $\begin{array}{l}\text { Delay in } \\
\text { completion of the } \\
\text { project work due to } \\
\text { misunderstanding } \\
\text { of design }\end{array}$ & 2.92 & 3.00 & 2.00 & 1.07 & 1.15 & $\begin{array}{l}0.61 \\
5\end{array}$ & 12 \\
\hline 6 & $\begin{array}{l}\text { The labors may be } \\
\text { Misunderstand the } \\
\text { drawing compare to } \\
\text { supervisors }\end{array}$ & 3.55 & 4.00 & 4.00 & 1.00 & 1.01 & $\begin{array}{l}048 \\
9\end{array}$ & 17 \\
\hline 7 & $\begin{array}{ll}\text { Difficulty in } \\
\text { understanding in } \\
\text { construction design }\end{array}$ & 2.92 & 3.00 & 3.00 & 0.881 & 0.777 & $\begin{array}{l}0.61 \\
5\end{array}$ & 12 \\
\hline 8 & $\begin{array}{l}\text { Shortage of } \\
\text { Communication } \\
\text { with foreign } \\
\text { operatives }\end{array}$ & 3.47 & 4.00 & 4.00 & 1.10 & 1.229 & $\begin{array}{l}0.50 \\
5\end{array}$ & 16 \\
\hline 9 & $\begin{array}{l}\text { Failure to provide } \\
\text { training for labors }\end{array}$ & 3.13 & 3.00 & 3.00 & 1.234 & 1.523 & $\begin{array}{l}0.50 \\
3\end{array}$ & 15 \\
\hline 10 & $\begin{array}{l}\text { Due to language the } \\
\text { communication } \\
\text { gets affected }\end{array}$ & 3.84 & 4.00 & 4.00 & 1.027 & 1.055 & $\begin{array}{l}0.43 \\
1\end{array}$ & 20 \\
\hline 11 & $\begin{array}{l}\text { Having less } \\
\text { information about } \\
\text { the sudden changes } \\
\text { in work a worksite }\end{array}$ & 3.47 & 3.5 & 3.00 & 0.95 & 0.905 & $\begin{array}{l}0.50 \\
5\end{array}$ & 16 \\
\hline 12 & $\begin{array}{l}\text { The changes made } \\
\text { in drawings can not } \\
\text { reaches to entire } \\
\text { labor force }\end{array}$ & 3.65 & 4.00 & 4.00 & 1.04 & 1.09 & $\begin{array}{l}0.73 \\
1\end{array}$ & 4 \\
\hline 13 & Technical & 3.42 & 4.00 & 4.00 & 0.948 & 0.899 & 0.68 & 7 \\
\hline
\end{tabular}




\begin{tabular}{|c|c|c|c|c|c|c|c|c|}
\hline & $\begin{array}{lr}\text { specification and } \\
\text { Alternation } \\
\text { drawings are shown } \\
\text { to workers with } \\
\text { clarity }\end{array}$ & & & & & & 4 & \\
\hline 14 & $\begin{array}{l}\text { Complex building } \\
\text { function leads to } \\
\text { difficulty in design }\end{array}$ & 3.39 & 3.50 & 4.00 & 0.886 & 0.786 & $\begin{array}{l}0.67 \\
8\end{array}$ & 8 \\
\hline 15 & $\begin{array}{l}\text { The physical } \\
\text { location of the } \\
\text { project site affects } \\
\text { by the } \\
\text { communication }\end{array}$ & 3.02 & 3.00 & 3.00 & 1.15 & 1.32 & $\begin{array}{l}0.60 \\
5\end{array}$ & 13 \\
\hline 16 & $\begin{array}{l}\text { The media used to } \\
\text { receive information } \\
\text { is accurately } \\
\text { attained }\end{array}$ & 3.42 & 3.50 & 4.00 & 0.826 & 0.683 & $\begin{array}{l}0.68 \\
4\end{array}$ & 7 \\
\hline 17 & $\begin{array}{l}\text { The information } \\
\text { passing through the } \\
\text { media is affected } \\
\text { due to the size of } \\
\text { crew }\end{array}$ & 3.42 & 3.00 & 3.00 & 0.889 & 0.791 & $\begin{array}{l}0.68 \\
9\end{array}$ & 6 \\
\hline 18 & $\begin{array}{l}\text { Top management } \\
\text { receive } \\
\text { communication } \\
\text { from bottom } \\
\text { line/middle } \\
\text { managers through } \\
\text { media }\end{array}$ & 3.39 & 3.00 & 3.00 & 1.151 & 1.326 & $\begin{array}{l}0.67 \\
8\end{array}$ & 8 \\
\hline 19 & $\begin{array}{l}\text { Improper } \\
\text { communication } \\
\text { between top and } \\
\text { bottom line leads to } \\
\text { poor quality and } \\
\text { productivity }\end{array}$ & 3.76 & 4.00 & 4.00 & 0.970 & 0.942 & $\begin{array}{l}0.75 \\
2\end{array}$ & 2 \\
\hline 20 & $\begin{array}{l}\text { The organization is } \\
\text { getting proper } \\
\text { feedback from the } \\
\text { middle level and } \\
\text { bottom line }\end{array}$ & 3.31 & 3.50 & 4.00 & 1.042 & 1.087 & $\begin{array}{l}0.66 \\
3\end{array}$ & 10 \\
\hline 21 & $\begin{array}{l}\text { The information } \\
\text { from the Top } \\
\text { management is }\end{array}$ & 3.50 & 4.00 & 4.00 & 1.10 & 1.23 & 0.7 & 5 \\
\hline
\end{tabular}




\begin{tabular}{|c|c|c|c|c|c|c|c|c|}
\hline & responding in delay & & & & & & & \\
\hline 22 & $\begin{array}{l}\text { The trust and good } \\
\text { spirit is formed } \\
\text { between } \\
\text { managers } \\
\text { labors }\end{array}$ & 3.71 & 4.00 & 4.00 & 1.037 & 1.076 & $\begin{array}{l}0.74 \\
2\end{array}$ & 3 \\
\hline 23 & $\begin{array}{l}\text { Relationship among } \\
\text { top management } \\
\text { and labour not } \\
\text { improved }\end{array}$ & 3.34 & 3.00 & 3.00 & 0.908 & 0.826 & $\begin{array}{l}0.66 \\
8\end{array}$ & 9 \\
\hline 24 & $\begin{array}{l}\text { The supervisor has } \\
\text { the ability to solve } \\
\text { the problem } \\
\text { between the labors }\end{array}$ & 4.00 & 4.00 & 4.00 & 0.900 & 0.811 & 0.8 & 1 \\
\hline 25 & $\begin{array}{l}\text { More number of } \\
\text { workers working at } \\
\text { site influences the } \\
\text { communication }\end{array}$ & 3.42 & 3.00 & 3.00 & 0.826 & 0.683 & $\begin{array}{l}0.68 \\
4\end{array}$ & 7 \\
\hline 26 & $\begin{array}{l}\text { The more number } \\
\text { of workers } \\
\text { employed } \\
\text { specifically for the } \\
\text { information } \\
\text { management }\end{array}$ & 3.00 & 3.00 & 3.00 & 0.929 & 0.865 & 0.6 & 4 \\
\hline 27 & $\begin{array}{l}\text { Disputes might } \\
\text { occurs between the } \\
\text { middle level and } \\
\text { bottom line due to } \\
\text { over controlling and } \\
\text { directing }\end{array}$ & 3.50 & 4.00 & 4.00 & 0.951 & 0.905 & 0.7 & 5 \\
\hline 28 & $\begin{array}{l}\text { The labors shows } \\
\text { attitude among the } \\
\text { project team }\end{array}$ & 3.28 & 3.00 & 3.00 & 0.98 & 0.968 & $\begin{array}{l}0.65 \\
7\end{array}$ & 11 \\
\hline 29 & $\begin{array}{l}\text { Decision making } \\
\text { affects due to Lack } \\
\text { of leadership } \\
\text { qualities the by } \\
\text { manager }\end{array}$ & 3.5 & 4.00 & 4.00 & 1.10 & 1.230 & 0.7 & 5 \\
\hline 30 & $\begin{array}{lr}\text { Egotism } & \text { occurs } \\
\text { between } & \text { middle } \\
\text { level } & \text { managers } \\
\text { while } & \text { making } \\
\text { decisions } & \end{array}$ & 3.39 & 3.00 & 3.00 & 1.027 & 1.05 & $\begin{array}{l}0.67 \\
8\end{array}$ & 8 \\
\hline
\end{tabular}




\begin{tabular}{|l|l|l|l|l|l|l|l|l|}
\hline 31 & $\begin{array}{l}\text { The supervisor } \\
\text { sends the } \\
\text { information are } \\
\text { correctly received } \\
\text { to the workers }\end{array}$ & 3.65 & 4.00 & 4.00 & 0.908 & 0.826 & 0.73 & 4 \\
32 & $\begin{array}{l}\text { Employee } \\
\text { grievances may not } \\
\text { be added properly } \\
\text { due to loss of } \\
\text { communicates }\end{array}$ & 3.34 & 3.00 & 3.00 & 0.847 & 0.718 & 0.66 & 9 \\
\hline
\end{tabular}

\section{Conclusion}

From the previous literature the factors has been identified and critical factors are considered as important. This paper found the most critical factors that affect the communication are Inaccuracy, Misunderstanding, Barriers, Project complexity, Communication media, Organization structure, Untimeliness. From the responses collected it was observed that the factors misunderstanding, Barriers, organizational structure affects the communication in the site. Relative important index was calculated to rank the factors. The supervisor has the ability to solve the problem between the labors ranks 1 and the factor trust among the workers is more. A special preventive measures should taken to overcome the communication problems in the construction site.

\section{References}

[1] Y. Gamil, I. A. Rahman, "Identification of causes and effects of poor communication in construction industry: A theoretical review”, Emerging Science Journal. vol. 1, no. 4, (2017), pp. 239-247.

[2] T. Aulich, "The role of effective communication in the construction Industry: a guide for education and health clients", Construction Economics and Building. Vol. 13, no. 4, (2013), pp. 92-101.

[3] A. Olanrewaju, S. Y. Tan, L. F. Kwan. Roles of communication on performance of the construction sector. Procedia engineering, vol. 196, (2017), pp. 763-770.

[4] S. R. Thomas, R. L. Tucker, W. R. Kelly, “Compass: An assessment tool for improving project team communications", Project Management Journal, vol. 30, no. 4, (1999), pp. $15-24$.

[5] S. M. Crampton, J. W. Hodge, J. M. Mishra, "The informal communication network: Factors influencing grapevine activity”, Public Personnel Management, vol. 27, no. 4, (1998), pp. 569-584.

[6] M. Hoezen, I. Reymen, G. Dewulf, "The problem of communication in construction", CIB W96 Adaptable Conference, University of Twente). (2006).

[7] M. Chmielecki, "Factors influencing effectiveness of internal communication. Management and Business Administration”, Central Europe, vol. 2, (2015), pp. 24-38.

[8] S. Mitkus, T. Mitkus, "Causes of conflicts in a construction industry: A communicational approach”, Procedia-Social and Behavioral Sciences, 110, (2014), pp. 777-786. 
[9] C. Anumba, G. Baron, N. Evbuomwan, "Communications issues in concurrent life-cycle design and construction” BT Technology Journal, vol. 15, no. 1, (1997), pp. 209-216.

[10] V. S. Di Salvo, "A summary of current research identifying communication skills in various organizational contexts", (1980)

[11] T. Shindina, "Organization of interaction between the participants in modern construction" Procedia Engineering, vol. 150, (2016), pp. 2113-2118.

[12] Bowen PA, Edwards PJ. 1996. Interpersonal communication in cost planning during the building design phase. Construction Management \& Economics. 14(5): 395-404.

[13] E. W. Cheng et al., "Network communication in the construction industry", Corporate Communications: An International Journal, (2001).

[14] E. Aiyewalehinmi. "Factor analysis of communication in the construction industry", The International Journal of Engineering and Science. Vol. 2, no. 10, (2013), pp. 49-57. 